\title{
From theory to practice, operating the clinical simulation in Nursing teaching
}

Da teoria à prática, operacionalizando a simulação clínica no ensino de Enfermagem

De la teoría a la práctica, operacionalizando la simulación clínica en la enseñanza de enfermería

\section{Saionara Nunes de Oliveira', Aline Massaroli", Jussara Gue Martini', Jeferson Rodrigues'}

' Universidade Federal de Santa Catarina, Laboratory of Research and Technologies in Education in Nursing and Health. Florianópolis, Santa Catarina, Brazil.

"Universidade Federal da Fronteira Sul, Laboratory of Research and Technologies in Education in Nursing and Health. Chapecó, Santa Catarina, Brazil.

How to cite this article:

Oliveira SN, Massaroli A, Martini JG, Rodrigues J. From theory to practice, operating the clinical simulation in Nursing teaching. Rev Bras Enferm [Internet]. 2018;71(Suppl 4):1791-8. [Thematic issue: Education and teaching in Nursing] DOI: http://dx.doi.org/10.1590/0034-7167-2017-0180

\section{Submission: 03-31-2017 Approval: 11-19-2017}

\begin{abstract}
Objective: To report the experience of the operationalization of clinical simulation as a pedagogical strategy in a subject of an undergraduate course in Nursing. Method: Clinical simulation cycles were carried out following the steps of action research, such as: planning, action, observation and reflection, from March 2014 to July 2015 with 10 professors and 44 students from a Primary Care and Mental Health subject of an undergraduate course in Nursing. Results: Five cycles of clinical simulation were performed, at the end of each cycle modifications were suggested by students and professors and the operation was adjusted to meet the needs of the subject. The main points of change were: professor role, logistics, equipment, debriefing model and preparation of "simulated patients". Final considerations: The clinical simulation is a possible method to be operationalized in undergraduate course in Nursing, needs pedagogical and logistic planning as well as, sensitization of professors and students.

Descriptors: Simulation; Nursing Education; Higher Education; Simulation of Patient; Mental Health.
\end{abstract}

\section{RESUMO}

Objetivo: Relatar a experiência da operacionalização da simulação clínica como estratégia pedagógica em uma disciplina de um curso de graduação em Enfermagem. Método: Foram realizados ciclos de simulação clínica seguindo os passos da pesquisaação, como: planejamento, ação, observação e reflexão, no período de março de 2014 a julho de 2015 com 10 professores e 44 estudantes de uma disciplina de Atenção Básica e Saúde Mental de um curso de graduação em Enfermagem. Resultados: Foram realizados 5 ciclos de simulação clínica, ao final de cada ciclo modificações foram sugeridas por estudantes e professores e a operacionalização foi sendo ajustada visando adequar-se às necessidades da disciplina. Os principais pontos de mudança foram: papel do professor, logística, equipamentos, modelo de debriefing e preparo dos "pacientes simulados". Considerações finais: A simulação clínica é um método possível de ser operacionalizado no curso de graduação em Enfermagem, necessita de planejamento pedagógico e logístico bem como, sensibilização de professores e estudantes.

Descritores: Simulação; Educação em Enfermagem; Ensino Superior; Simulação de Paciente; Saúde Mental.

\section{RESUMEN}

Objetivo: Informar la experiencia de la operacionalización de la simulación clínica como estrategia pedagógica en una disciplina de un curso de graduación en enfermería. Método: Se realizaron ciclos de simulación clínica siguiendo los pasos de la investigación-acción: planificación, acción, observación y reflexión, en el período de marzo de 2014 a julio de 2015 con 10 profesores y 44 estudiantes de una disciplina de atención básica y salud mental de un curso de graduación en enfermería. Resultados: Se realizaron 5 ciclos de simulación clínica; al final de cada ciclo, modificaciones fueron sugeridas por estudiantes y profesores y la operacionalización fue ajustada para adecuarse a las necesidades de la disciplina. Los principales puntos de cambio fueron: papel del profesor, logística, equipamientos, modelo de debriefing y preparación de los Pacientes Simulados. 
Consideraciones finales: La simulación clínica es un método posible de ser operacionalizado en el curso de graduación en enfermería, necesita de planificación pedagógica y logística así como de la sensibilización de profesores y estudiantes.

Descriptores: Simulación; Educación en Enfermería; Enseñanza Superior; Simulación de Paciente; Salud Mental.

\section{CORRESPONDING AUTHOR Saionara Nunes de OliveiraＥ-mail: saionaranunes@gmail.com}

\section{INTRODUCTION}

The need to develop systems that promote the safety of patients and professionals in health services intensifies and instigates reflection on the work process in the health area and on the teaching of new professionals.

In education, the debate about patient safety develops from two perspectives, one that seeks to ensure that students develop the skills necessary to assist patients safely, and another that expects the process of teaching and learning students do not expose the actual patients to unnecessary risks.

Clinical simulation is an experiential learning-oriented pedagogical strategy that meets both needs by bringing students and practitioners together in real simulated contexts, providing complete security for those involved ${ }^{(1-2)}$.

This strategy, at the operational moment, has as its stages the briefing, scene and debriefing. The briefing is constituted by the basic orientations that the student receives before starting his / her performance in a simulated setting, such as a passage on duty in which the clinical picture is described. The scene is the moment of the simulation in which the case has an outcome depending on the intervention of the student. The debriefing, which occurs shortly after the scene, includes the last step in which the student and the professor reflect on what happened and punctuate what might or may not have been done differently ${ }^{(3)}$.

For the development of clinical simulation, it is possible to use low, medium and high technology simulators as well as people in the role of patients, the so-called "simulated patients" or "standardized" patients who are considered high fidelity because they authentically replicate situations clinics and provide real interactions for students ${ }^{(4)}$.

Several studies confirm the efficiency of this pedagogical strategy to boost the clinical, critical and reflective thinking of the student ${ }^{(2-3,5)}$, however, the operationalization of clinical simulation still constitutes a challenge for the Teaching Institutions due to the physical resources and human resources associated with the large number of students in each class. A study pointed out that the logistics end up being the largest obstacle for the implementation of the clinical simulation ${ }^{(6)}$.

In this perspective, the purpose of this study was to report on the experience of the operationalization of clinical simulation as a pedagogical strategy in a subject of one of the subjects that deals with Nursing care in the context of Primary Care and Mental Health. undergraduate course in Nursing.

\section{METHOD}

This is an experience report on the operationalization of clinical simulation as a pedagogical strategy in a Primary Care and Mental Health subject of an undergraduate course in Nursing at a public university in the south of Brazil.

The course had a workload of 432 hours and had 12 professors with expertise in Primary Care or Mental Health, and of these, two participated only in theoretical classes. Before starting the first cycle of simulation, wheels of conversations were realized between the professors of the subject for theoretical discussion of the concept and understanding of the group on clinical simulation.

The experiment culminated in 5 clinical simulation cycles, the first three of which occurred in February 2014 and the last two in January 2015. In the two semesters in which the clinical simulation was developed in the subject, there were respectively 18 and 26 students. The 10 professors who participated in the theoretical and practical activities of the subject participated in the whole process.

Each cycle of clinical simulation counted on the planning stages, to define the way of organization of students and professors, and elaboration of clinical guidelines; action: where the clinical simulation was developed from the stages of briefing, scene and debriefing; After the debriefing was finalized, a conversation was held with the students and professors to discuss the weaknesses and potentialities of the operation of clinical simulation, the statements were recorded in audio and later transcribed, and the information grouped by similarity of the ideas; and reflection: where the professors analyzed in depth the observations made on the talk wheels and defined the adjustments that would be made in the next cycle. For the development of the clinical simulation, it was defined that the clinical situations would be related to Mental Health, articulated in order to boost the student to develop therapeutic listening and to identify the real cause of the search for the health service. To do so, the student performed a nursing consultation with a "simulated patient" to identify the problem presented and define a behavior for care.

The "simulated patients" were interpreted by volunteers participating in a university extension project that focused on the humanization of health care. Their preparation counted on the discussion of the clinical situations, specifying the usual behavior of a real patient in said condition, as well as the definition of the attitude of the "simulated patient" before the possible actions of the student, with a test moment for improvement and adjustment of the participant's interpretation.

Each simulation cycle counted on the construction of Clinical Guides that were composed by the following fields: description of the clinical situation, objective, expected competences; fictitious medical records; script of the clinical situation adapted to the "simulated patients" (containing details about the character and about the unfolding of the scene); setting (description of the environment in which the scene occurs) and the professor's follow-up checklist. The previous evaluation of the clinical guidelines was carried out by the professors of the subject who received the material via electronic mail and could make adjustments to the final version. 
Ethical aspects were respected in accordance with Administrative Ordinance 466/2012, under Opinion 724.426 of the Ethics Committee on Human of the Universidade Federal de Santa Catarina.

\section{RESULTS}

The clinical simulation was defined by the subject as a formative activity, unrelated to the summative evaluation or attribution of a note, seeking to make the students calmer for the accomplishment of the service and the debriefing. Chart 1 shows the main elements that were present in each stage of the 5 cycles, allowing the visualization of the modifications and adjustments made in each one of them.

Among the changes made in each cycle, the number of components in each group and the professors' distribution were the main changes occurred in the first semester (cycles 1, 2 and 3) for the second semester (cycles 4 and 5) of simulation development clinic In figures 1, 2 and 3 it is possible to observe the movements performed in the simulation cycles to operationalize this strategy.

Chart 1 - Description of the elements that composed each step of the 5 simulation cycles

\begin{tabular}{|c|c|c|c|c|c|}
\hline $\begin{array}{l}\text { Operationalization } \\
\text { stages }\end{array}$ & Cycle 1 & Cycle 2 & Cycle 3 & Cycle 4 & Cycle 5 \\
\hline Clinical Guides & $\begin{array}{l}\text { Prepared by } 3 \\
\text { professors. }\end{array}$ & $\begin{array}{l}\text { Elaborated by } 7 \\
\text { professors and } \\
\text { discussed with } \\
\text { everyone. }\end{array}$ & $\begin{array}{l}\text { Prepared by } 3 \\
\text { professors and } \\
\text { discussed with } \\
\text { everyone. }\end{array}$ & $\begin{array}{l}\text { Prepared by } 3 \\
\text { professors and } \\
\text { discussed with } \\
\text { everyone. }\end{array}$ & $\begin{array}{l}\text { Prepared by } 3 \\
\text { professors and } \\
\text { discussed with } \\
\text { everyone. }\end{array}$ \\
\hline Setting & $\begin{array}{l}3 \text { practice rooms } \\
\text { and } 1 \text { waiting } \\
\text { room (adapted in } \\
\text { classrooms). }\end{array}$ & $\begin{array}{l}3 \text { practice rooms } \\
\text { and } 1 \text { waiting } \\
\text { room (adapted in } \\
\text { classrooms). }\end{array}$ & $\begin{array}{l}1 \text { practice room } \\
\text { and } 1 \text { waiting } \\
\text { room (use of } \\
\text { clinical simulation } \\
\text { laboratory). }\end{array}$ & $\begin{array}{l}1 \text { practice room and } \\
1 \text { waiting room (use } \\
\text { of clinical simulation } \\
\text { laboratory). }\end{array}$ & $\begin{array}{l}1 \text { practice room and } \\
1 \text { waiting room (use } \\
\text { of clinical simulation } \\
\text { laboratory). }\end{array}$ \\
\hline $\begin{array}{l}N^{\circ} \text { of "Simulated } \\
\text { Patients" required } \\
\text { per day }\end{array}$ & 3 & 3 & 3 & 1 & 1 \\
\hline Days of the activity & 2 & 2 & 1 & 2 & 2 \\
\hline $\mathrm{N}^{0}$ of students/class & 18 & 18 & 18 & 26 & 26 \\
\hline $\mathrm{N}^{0}$ of students/group & 6 & 6 & 6 & $\begin{array}{l}\text { A group of } 12 \text { and } \\
\text { one of } 14 .\end{array}$ & $\begin{array}{l}\text { A group of } 12 \text { and } \\
\text { one of } 14 .\end{array}$ \\
\hline $\begin{array}{l}N^{0} \text { of professors/ } \\
\text { group }\end{array}$ & 2 & 2 & 2 & 4 & 4 \\
\hline Debriefing & $\begin{array}{l}\text { Carried out by } 2 \\
\text { professors: } 1 \text { from } \\
\text { Primary Care and } \\
1 \text { from Mental } \\
\text { Health. Collective. }\end{array}$ & $\begin{array}{l}\text { Carried out by } 2 \\
\text { professors: } 1 \text { from } \\
\text { Primary Care and } \\
1 \text { from Mental } \\
\text { Health. Collective. }\end{array}$ & $\begin{array}{l}\text { Carried out by } 2 \\
\text { professors: } 1 \text { from } \\
\text { Primary Care and } \\
1 \text { from Mental } \\
\text { Health. Collective. }\end{array}$ & $\begin{array}{l}\text { Carried out by } 4 \\
\text { professors: } 1 \text { from } \\
\text { Primary Care, } 1 \text { from } \\
\text { Mental Health and } 2 \\
\text { from the simulation } \\
\text { committee. } \\
\text { Collective. }\end{array}$ & $\begin{array}{l}\text { Carried out by } 4 \\
\text { professors: } 1 \text { from } \\
\text { Primary Care, } 1 \text { from } \\
\text { Mental Health and } 2 \\
\text { from the simulation } \\
\text { committee. } \\
\text { Collective. }\end{array}$ \\
\hline Recording & Yes & Yes & Yes & Yes & Yes \\
\hline $\begin{array}{l}\text { Simultaneous } \\
\text { transmission }\end{array}$ & Yes & No & No & No & No \\
\hline $\mathrm{N}^{0}$ of students/setting & 1 & 2 & 2 & 2 & 2 \\
\hline Checklist & $\begin{array}{l}\text { For Professor: } 40 \\
\text { items }\end{array}$ & $\begin{array}{l}\text { For Professor: } 40 \\
\text { items }\end{array}$ & $\begin{array}{l}\text { For Professor: } 40 \\
\text { items }\end{array}$ & $\begin{array}{l}\text { For Professor: } 11 \\
\text { items } \\
\text { For students who } \\
\text { attended the } \\
\text { attendance } 5 \text { items. } \\
\text { For students who } \\
\text { attended } 4 \text { items }\end{array}$ & $\begin{array}{l}\text { For Professor: } 11 \\
\text { items } \\
\text { For students who } \\
\text { attended the } \\
\text { attendance } 5 \text { items. } \\
\text { For students who } \\
\text { attended } 4 \text { items. }\end{array}$ \\
\hline Setbacks & $\begin{array}{l}\text { - } 60 \text { minutes delay } \\
\text { to start activities } \\
\text { - Problems with } \\
\text { equipment for } \\
\text { simultaneous } \\
\text { transmission }\end{array}$ & $\begin{array}{l}\text { - Delay of } 30 \\
\text { minutes to start } \\
\text { activities } \\
\text { - Absence of several } \\
\text { students. }\end{array}$ & & & \\
\hline
\end{tabular}




\begin{tabular}{|c|c|c|c|c|c|}
\hline $\begin{array}{l}\text { Operationalization } \\
\text { stages }\end{array}$ & Cycle 1 & Cycle 2 & Cycle 3 & Cycle 4 & Cycle 5 \\
\hline $\begin{array}{l}\text { Observations made } \\
\text { at meetings with } \\
\text { professors and } \\
\text { students }\end{array}$ & $\begin{array}{l}\text { - A very productive } \\
\text { strategy, boosts the } \\
\text { reflection of those } \\
\text { involved. } \\
\text { - The students } \\
\text { felt judged and } \\
\text { evaluated with } \\
\text { simultaneous } \\
\text { transmission. } \\
\text { - The students } \\
\text { missed a road map } \\
\text { for attendance. } \\
\text { - Lack of a } \\
\text { previous moment } \\
\text { the activity to } \\
\text { discuss collectively } \\
\text { with students the } \\
\text { teaching strategy } \\
\text { and its objectives. }\end{array}$ & $\begin{array}{l}\text { - Divergence of } \\
\text { opinion among } \\
\text { students about the } \\
\text { productivity of } \\
\text { clinical simulation } \\
\text { for learning. } \\
\text { - Requested that } \\
\text { the groups discuss } \\
\text { the will to continue } \\
\text { with the activity at } \\
\text { the third expected } \\
\text { time. }\end{array}$ & $\begin{array}{l}\text { - The students } \\
\text { emphasized that } \\
\text { the possibility } \\
\text { of watching the } \\
\text { video of the } \\
\text { service makes } \\
\text { them reflect on } \\
\text { their attitude, } \\
\text { actions and } \\
\text { decision making. } \\
\text { - There was a } \\
\text { growth of the } \\
\text { students in } \\
\text { the process of } \\
\text { realizing and } \\
\text { receiving the } \\
\text { positive and } \\
\text { negative critics } \\
\text { about each } \\
\text { service. }\end{array}$ & $\begin{array}{l}\text { - Students } \\
\text { highlighted the } \\
\text { productivity of } \\
\text { the strategy and } \\
\text { boostd reflection } \\
\text { on the need for } \\
\text { listening and the } \\
\text { humanization of } \\
\text { care. } \\
\text { - Suggestion to } \\
\text { record at the } \\
\text { beginning of the } \\
\text { morning all the calls } \\
\text { to later start the } \\
\text { debriefing. }\end{array}$ & $\begin{array}{l}\text { - The diversification } \\
\text { of clinical cases was } \\
\text { considered very } \\
\text { positive. } \\
\text { - The students } \\
\text { emphasized again } \\
\text { the importance of } \\
\text { using this strategy to } \\
\text { reflect their actions } \\
\text { and also to perceive } \\
\text { the weaknesses of } \\
\text { knowledge. } \\
\text { - The operational } \\
\text { structure was } \\
\text { evaluated as very } \\
\text { productive. }\end{array}$ \\
\hline Reflections & $\begin{array}{l}\text { - Productive and } \\
\text { viable strategy, } \\
\text { requiring } \\
\text { adjustments to } \\
\text { achieve the goal. } \\
\text { - Review the } \\
\text { quality of the } \\
\text { equipment used. } \\
\text { - The need for a } \\
\text { previous meeting } \\
\text { with all professors } \\
\text { involved in } \\
\text { conducting the } \\
\text { clinical simulation } \\
\text { groups on the } \\
\text { clinical case and } \\
\text { the focus of the } \\
\text { debriefing. } \\
\text { - Need to have } \\
\text { a later time to } \\
\text { theoretically } \\
\text { discuss with } \\
\text { students the } \\
\text { weaknesses } \\
\text { evidenced. }\end{array}$ & $\begin{array}{l}\text { - The need for } \\
\text { a collective } \\
\text { engagement of the } \\
\text { group of professors } \\
\text { for the success of } \\
\text { the strategy. } \\
\text { - The opinion } \\
\text { of the professor } \\
\text { accompanying the } \\
\text { group has a great } \\
\text { influence on the } \\
\text { students' opinion. } \\
\text { - Professors need to } \\
\text { have more control } \\
\text { over the conduct of } \\
\text { clinical simulation } \\
\text { and especially } \\
\text { about debriefing. }\end{array}$ & $\begin{array}{l}\text { - The need to } \\
\text { develop clinical } \\
\text { simulation as } \\
\text { a potential } \\
\text { pedagogical } \\
\text { strategy for the } \\
\text { development } \\
\text { of reflection, } \\
\text { criticality and } \\
\text { autonomy of } \\
\text { students. } \\
\text { - It is necessary } \\
\text { to create a new } \\
\text { operational } \\
\text { structure to } \\
\text { develop clinical } \\
\text { simulation in the } \\
\text { subject, aiming } \\
\text { to reduce the } \\
\text { number of rooms } \\
\text { in activities } \\
\text { simultaneously } \\
\text { and a way to have } \\
\text { greater uniformity } \\
\text { in the conduct of } \\
\text { the debriefing. }\end{array}$ & $\begin{array}{l}\text { - The lower } \\
\text { number of settings } \\
\text { allowed for more } \\
\text { tranquility in the } \\
\text { development of the } \\
\text { attendances, having } \\
\text { availability of } \\
\text { quality equipment } \\
\text { to record and attend } \\
\text { the attendances. } \\
\text { - The structure used } \\
\text { to operationalize } \\
\text { favored that the } \\
\text { conduction of the } \\
\text { debriefing had } \\
\text { similar focuses } \\
\text { of discussion of } \\
\text { clinical cases. } \\
\text { - Discussion with } \\
\text { professors is needed } \\
\text { on how to intervene } \\
\text { with students at the } \\
\text { time of debriefing. } \\
\text { - Having two } \\
\text { committee } \\
\text { professors in the } \\
\text { group led to the } \\
\text { achievement of the } \\
\text { expected objectives. }\end{array}$ & $\begin{array}{l}\text { - Simulation is a } \\
\text { strategy that boosts } \\
\text { the reflection of } \\
\text { the student and } \\
\text { professors and } \\
\text { allows the student } \\
\text { to attend critical } \\
\text { cases without risk } \\
\text { to himself or the } \\
\text { patient. } \\
\text { - Conducting the } \\
\text { debriefing by } \\
\text { professors who were } \\
\text { deeply involved } \\
\text { with the strategy, } \\
\text { provides better } \\
\text { development and } \\
\text { achievement of } \\
\text { expected objectives. } \\
\text { - The organization of } \\
\text { larger groups proved } \\
\text { to be productive and } \\
\text { viable. }\end{array}$ \\
\hline
\end{tabular}

In cycle 1, the simultaneous transmission of the attendances to the debriefing room and the recording of them in a video device was performed. In this cycle, the video of the attendance was resumed at the time of debriefing only to review the points considered critical by the professors.

After cycle 2, this procedure was modified, excluding the simultaneous transmission of the service and only the recording remained, so the debriefing provided a time for the video of the service to be initially assisted by the group and then continue the discussion.

It should be noted that in cycles 1,2 and 3, students were divided into 3 groups of 6 students, and the activity schemes illustrated in Figures 1 and 2 occurred simultaneously for the 3 groups in two days of activities, counting presence of all students. In cycle 3, the activity was only developed for one group on a day of activity.
In cycles 4 and 5 (figures 2 and 3), students were divided into 2 groups of 12 and 14 students, each group participating in one of the days of simulation activity. In cycle 4, half of the students performed the service and the other half participated exclusively at the time of debriefing. In cycle 5, the students who attended and participated exclusively in the debriefing.

As in cycles 4 and 5, each day of activity had a group of students, the process of operationalization was favored and facilitated due to the availability of more professors to assist in recording attendance; a fixed setting of the university simulation center; of equipment of higher resolution and quality for the recording of the attendances and to assist them later in the moment of the debriefing; and to enable the participation of professors of the simulation committee in conducting the debriefing on both days. 


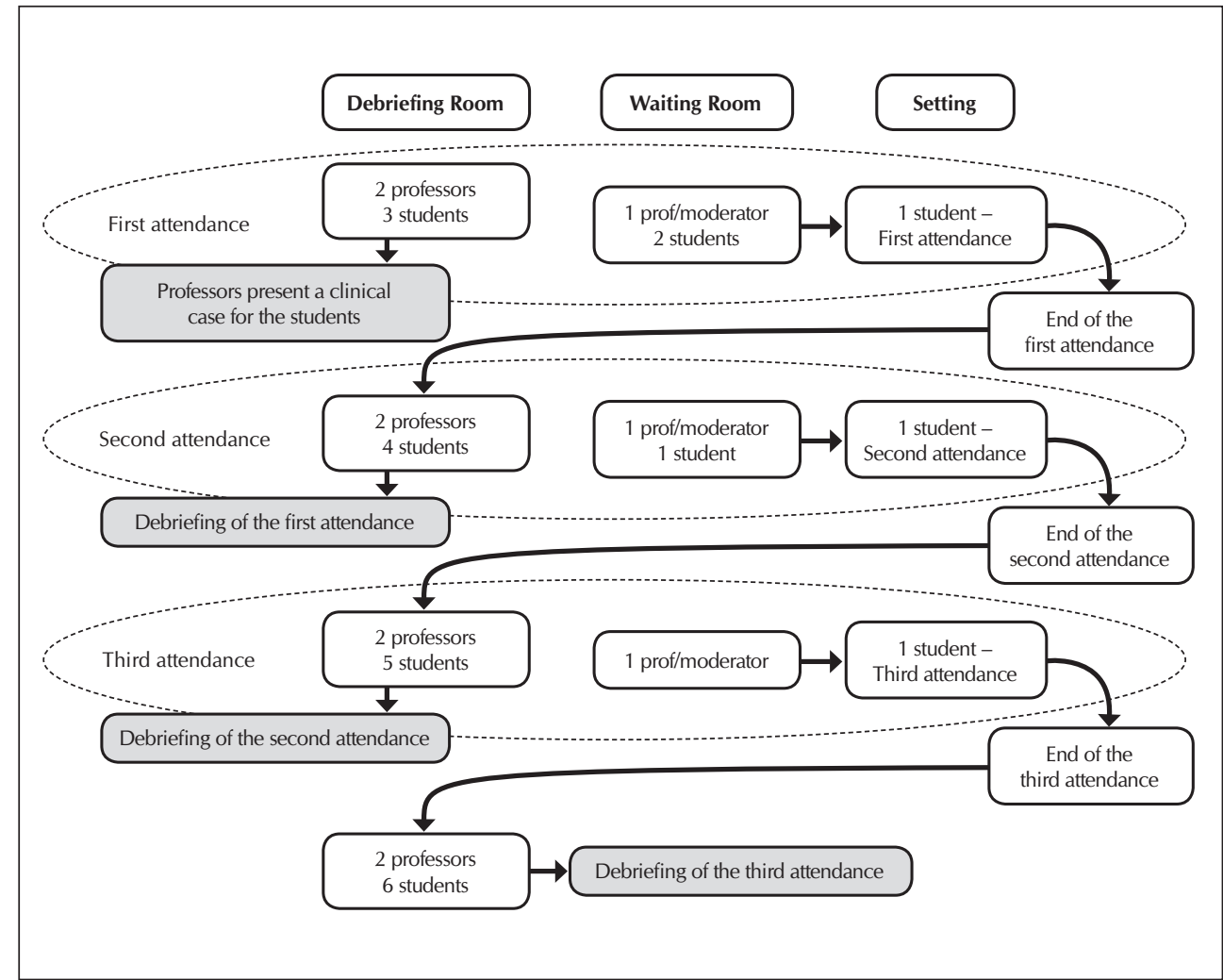

Figure 1 - Scheme illustrating the operationalization of cycle 1 of clinical simulation in one day of activity in a group of 6 students

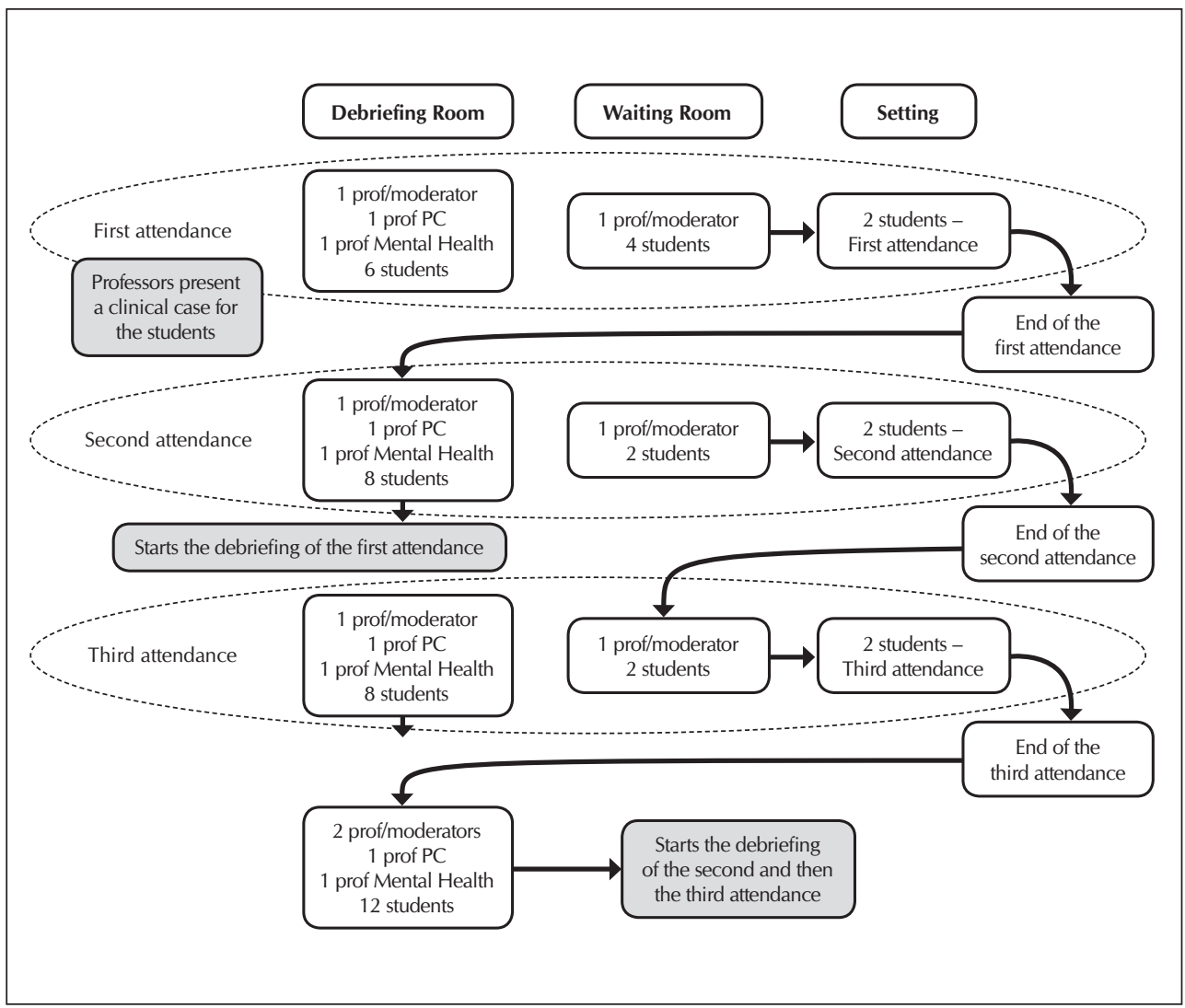

Figure 2 - Scheme illustrating the operationalization of clinical simulation cycle 4 in one day of activity in a group of 12 students

\section{DISCUSSION}

The use of clinical simulation as a pedagogical strategy for the teaching of health students has been growing and consolidating every day. A recent study shows that it can replace up to $50 \%$ of clinical practices without impairing the quality of training(7).

Currently, what needs to be discussed is how the simulation is used and operationalized, as well as the professor preparation for its application, since they are determinant factors in the success of this strategy ${ }^{(8)}$.

The clinical simulation allows the professor to follow the development of the student in the cognitive, motor and relational aspects, issuing constructive feedbacks that help to improve the student, which is in line with what is proposed in the formative evaluation ${ }^{(8)}$.

The inverse situation is observed in traditional teaching, where teaching strategies are still linked to summative evaluation, which generates anxiety and fear in the student, generating barriers and difficulties for the development of learning ${ }^{(9)}$. To make it clear from the outset that the simulation would not have summative evaluative character was of great importance for the students' adherence to this pedagogical strategy that was new to them.

The process of implementing a new teaching method makes professors and students initially feel insecure, which is understandable since they do not fully dominate the new proposal and must break with the traditional model in which professor is still the center and the student his spectator who "imitates" the master ${ }^{(10)}$. 


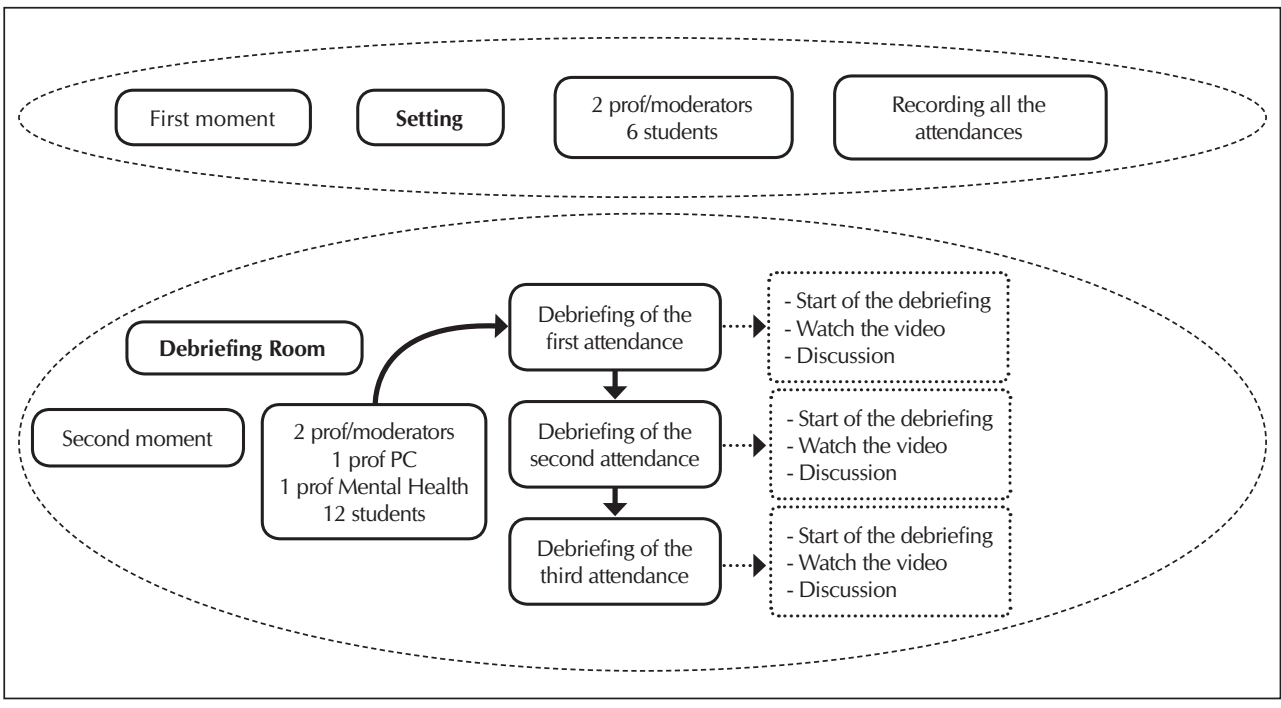

Figure 3 - Scheme illustrating the operationalization of cycle 5 of clinical simulation in one day of activity in a group of 12 students

In Nursing, teaching by demonstrating techniques and procedures in a simulated way is not something new or recent. For many years, puppets, oranges and other artifacts have been used in laboratories for the teaching process, in order to better prepare the student for the moment of direct contact with the real patient ${ }^{(11)}$.

However, the clinical simulation has a proposal of differentiated operationalization, which seeks to instigate the student's reflection based on his actions and his knowledge, surpassing the repetition of actions demonstrated by the professor, thus becoming the center of the teaching process that is supported and mediated by the professor. This change in perspective leads to greater apprehension on the part of professors for being slightly different from the conventional ${ }^{(11)}$.

Initially, there was less involvement of professors with the elaboration of clinical guidelines and setting of the settings, which was gradually overcome until all contributed to the definition of the simulated session objective, the clinical case and the improvement of the operation of clinical simulation.

In 2005, Jeffries published the NLN/Jeffries Simulation Framework project which aims to guide the design, implementation, and evaluation of simulated nursing practice. Revised in 2010, the framework provides for the preparation of the facilitator, the participant, the educational practice, the design and the evaluation method. One of the aspects addressed in this proposal is the design of clinical simulation that includes: objectives, fidelity, problem solving, student support and debriefing ${ }^{(12)}$.

The definition of the learning objective by the simulation is the first step in this process and should be delimited collectively among professors. To achieve the desired results, the goal should address the domains of cognitive, affective and psychomotor learning; correspond to the level of knowledge and clinical experience of the participant; be congruent with the overall results of the course; incorporate evidence-based practice; include visualization of comprehensive care; and be feasible within the time available for the simulation ${ }^{(13)}$.
We noticed that when focusing on a single objective (to classify the risk of suicide), in the last cycle of the simulation, that the setting was elaborated more easily, the professors were more comfortable at the time of debriefing and the reflection was more in-depth.

With a clear goal, the student was able to prepare better and apply theoretical knowledge in simulated practice. In the first cycles, as the objectives were broad, there was a lot of content to be studied previously and the students did not perform well in the conduct of the service, which generated a lot of discomfort in them.

In addition to being aware of the purpose of learning, students need to know the teaching method. In the first cycle, the students showed some fear of participating in the simulation, they affirmed that the simultaneous transmission caused discomfort because they felt "observed" and "judged" by their colleagues, which showed the students' lack of familiarity with the proposal of clinical simulation. the same search for collaborative learning, in which experiences, positive or negative, are the starting point for reflection and joint growth ${ }^{(14)}$.

This evaluation was important so that we included the preparation of the student in the next cycle, having a previous moment with them to present all the stages of the simulation, the objectives, the importance of the strategy in the formation and together with them we thought about adjustments so that the process more quietly and productively for all.

In this sense, it is important that the students are familiar with the proposal, know the objectives, the simulated environment and the available technologies, and it is up to the professor to sensitize them to this moment of exchange and construction of knowledge.

The reality of this subject where the clinical simulation was implemented is from classes of 20 to 38 students, which makes the professor need to plan the operation of the clinical simulation sessions, distributing them so that the spaces and time spent are optimized.

This was one of the major challenges in this process, since the large number of students and the limitation of physical structure and equipment required the development of a great exercise of articulation and adaptation, in order to find, throughout the process, the best logistics to reach the full potential of clinical simulation as a pedagogical strategy.

Throughout the five cycles of clinical simulation, different distribution formats of students and professors were used as shown in Figures 1 and 2, and the one that best met the needs of the subject and the physical structure and technological and human resources available was the model of cycle 5 (Figure 3 ), when all the scenes were individually recorded at a first moment and the debriefing occurred in sequence collectively. 
The option adopted from the second cycle, in which the service was recorded without simultaneous transmission and later, at the time of the collective debriefing, the recording of the service was started, it was very positive. Observing his own performance with the audiovisual resource instigated the student to reflect spontaneously on his actions and attitude in front of the patient.

The appropriate clinical simulation strategy is conditioned to the proposed learning objective and the pedagogical conception employed, adapting each session to the use of a simulator and a setting that best meet the needs of each moment. For example, cardiorespiratory resuscitation maneuvers require manikins for performing chest compression to reproduce the resistance of a human chest. For the development of communication, it is necessary to have a simulator that interacts with the student who, in addition to speaking, manifests non-verbal communication, in which case the "simulated patient" is the most appropriate.

The use of "simulated patients" for the development of nursing consultations contributed to the realistic interpretation of the settings, allowing the students to explore, in a safe and non-threatening environment, their fears and anxieties related to the care of patients with Mental Health Disorders ${ }^{(15)}$.

The "simulated patient" needs to receive previous training, both to understand their role in the training of students and to know the reactions expected during the attendance and the student's attitudes ${ }^{(16)}$.

In this study, the construction of a detailed clinical guide, with information about the previous history in non-technical language, describing the emotional state, attitude, possible outcomes and related answers was fundamental for the preparation and interpretation of the "simulated patients" in Mental Health, minimizing the representation of common-sense stereotypes.

Another point that favored the last simulations was the availability of a simulated practice room in the simulation center, which did not happen in the first cycles when the simulated practice room had to be improvised in a classroom.

Environmental fidelity is extremely important, being defined as the degree to which the simulated environment (dummy, room, tools, equipment, draping and sensory props) replicates the reality and appearance of the real environment. In this case, the use of "simulated patient", associated to the setting of nursing practice room contributed to the achievement of a high fidelity simulation, since they offered a high level of interactivity and realism for the student ${ }^{(17)}$.

Debriefing is the key moment of clinical simulation, when the student observes their behavior, reflects on it and understands what is missing for competence to be achieved. For this moment not to be prejudiced, the professor must understand it as a moment of the student and restrain himself from turning it into a lecture ${ }^{(18)}$.

The collective debriefing allowed, in addition to the acquisition of the skills proposed by the simulation, the exercise of skills such as working as a team, knowing how to identify weaknesses in a constructive way, exercising ethical behavior, perceiving different ways of addressing the same clinical context, the mistakes of his or his colleagues and the criticisms.

The way the professor conducts this moment is decisive in determining whether this will be a positive or negative experience in a students' academic life. If the professor is careful in his/her assignments, exalt the positive points and allow the student to identify the fragile aspects of his/her performance, he/she will be contributing to meaningful and constructive experiential learning. Otherwise, if the professor focuses only on the error, exposing the student to the group ignoring the positive aspects of the attendance, the student will feel diminished and this experience may hinder the construction of knowledge ${ }^{(18)}$.

The constant evaluation of the progress of the new proposal favored its improvement, since it was possible to adapt to the reality both material resources and the profile of the subject, professors and students.

As contributions to the area of Nursing and Health, it is emphasized that the use of clinical simulation as a pedagogical strategy should be boosted in nursing teaching, seeking a safer education for students and patients. Sharing possibilities of operationalizing clinical simulation for a large group of students is extremely important so that other institutions can make the use of this pedagogical strategy viable.

\section{FINAL CONSIDERATIONS}

The implementation of clinical simulation as a pedagogical strategy has proved to be a complex process, which needs to be open to suggestions and adaptations, allowing the best means to operationalize the logistics of this process, so that the expected objectives can be achieved.

The use of "simulated patients" to work on the communication skills, listening and perception of the real problem presented by the patient, was highly effective, as well as the option to perform the collective debriefing with a group of students, boosting them to discuss the aspects that can be continued and those that need to be reviewed and rethought during patient care.

It is necessary that other studies be developed addressing the aspects related to the operationalization of clinical simulation for larger groups of students, seeking to build new possibilities that enable the use of simulation in different teaching situations.

\section{REFERENCES}

1. Jensen S, Kushniruk AW, Nohr C. Clinical simulation: a method for development and evaluation of clinical information systems. J Biomed Inform [Internet]. 2015[cited 2016 Jul 20];54:65-76. Available from: http://www.ncbi.nlm.nih.gov/pubmed/25684129

2. Hope A, Garside J, Prescott S. Rethinking theory and practice: pre-registration student nurses experiences of simulation teaching and learning in the acquisition of clinical skills in preparation for practice. Nurse Educ Today[Internet]. 2011 [cited 2016 Jul 20];31(7):711-5. Available from: http://www.ncbi.nlm.nih.gov/pubmed/21237536 
3. Oliveira SN, Prado ML, Kempfer SS, Martini JG, Caravaca-Morera JA, Bernardi MC. Experiential learning in nursing consultation education via clinical simulation with actors: action research. Nurse Educ Today [Internet]. 2015[cited 2016 Jul 22];35(2):50-4. Available from: http://www.ncbi.nlm.nih.gov/pubmed/25563657

4. Jeffries PR. Simulation in nursing education: from conceptualization to evaluation. New York: National League for Nursing; 2007.

5. Gunningberg L, Pöder U, Carli C. Facilitating student nurses' learning by real time feedback of positioning to avoid pressure ulcers: evaluation of clinical simulation. J Nurs Educ Practice [Internet]. 2016[cited 2016 Aug 05];6(1):1-8. Available from: http://www. sciedupress.com/journal/index.php/jnep/article/view/6566

6. Quilici AP, Bicudo AM, Gianotto-Oliveira R, Timerman S, Gutierrez F, Abrão KC. Faculty perceptions of simulation programs in healthcare education. Int J Med Educ [Internet]. 2015[cited 2016 Aug 07];22(6):166-71. Available from: http://www.ncbi.nlm.nih. gov/pmc/articles/PMC4662865/

7. Hayden J, Smiley R, Alexander MA, Kardong-Edgren S, Jeffries P. The NCSBN National Simulation Study: a longitudinal, randomized, controlled study replacing clinical hours with simulation in prelicensure nursing education. J Nurs Regulation [Internet]. 2014 [cited 2016 Aug 07];5(2):S3-S40. Available from: https://www.ncsbn.org/JNR_Simulation_Supplement.pdf

8. Gomez MV, Vieira JE, Scalabrini Neto A. The background of professors in health fields that use simulation as a teaching strategy. Rev Bras Educ Med [Internet]. 2011[cited 2016 Aug 07];35(2):157-62. Available from http://www.scielo.br/pdf/rbem/v35n2/03.pdf

9. Leite SAS, Kager S. Efeitos aversivos das práticas de avaliação da aprendizagem escolar. Ensaio: Aval Pol Públ Educ[Internet]. 2009[cited 2016 Jun 22];17(62):109-34. Available from http://www.scielo.br/pdf/ensaio/v17n62/a06v1762.pdf

10. Mesquita SKC, Meneses RMV, Ramos DKR. Active teaching/learning methodologies: difficulties faced by the faculty of a nursing course. Trab Educ Saúde[Internet]. 2016[cited 2016 Jun 22];14(2):473-86. Available from: http://www.scielo.br/pdf/tes/v14n2/16781007-tes-1981-7746-sip00114.pdf

11. Martins JCA, Mazzo A, Baptista RCN, Coutinho VRD, Godoy S, Mendes IAC, et al. The simulated clinical experience in nursing education: a historical review. Acta Paul Enferm [Internet]. 2012[cited 2016 Jun 22];25(4):619-25. Available from: http://www. scielo.br/pdf/ape/v25n4/en_22.pdf

12. Groom JA, Henderson D, Sittner BJ. NLN/Jeffries simulation framework state of the science project: simulation design characteristics. Clin Simul Nurs[Internet]. 2014[cited 2016 Aug 06];10(7):337-44. Available from: http://www.nursingsimulation.org/article/ S1876-1399(13)00036-4/pdf

13. Lioce L, Reed CC, Lemon D, King MA, Martinez PA, Franklin AE, et al. Standards of best practice: simulation standard III: participant objectives. Clin Simul Nurs[Internet]. 2013[cited 2016 Aug 10];9(6):S15-S18. Available from: http://www.nursingsimulation.org/ article/S1876-1399(13)00075-3/fulltext

14. Decker S, Fey M, Sideras S, Caballero S, Rockstraw L, Boese T, et al. Standards of best practice: simulation standard VI: the debriefing process. Clin Simul Nurs[Internet]. 2013[cited 2016 Aug 15];9(6S):S27-S29. Available from: http://www.nursingsimulation.org/ article/S1876-1399(13)00079-0/fulltext

15. Davis JM. Implementation of mental health simulations: challenges and lessons learned. Clin Simul Nurs[Internet]. 2013[cited 2016 Aug 20];9(5):e157-e162. Available from: http://dx.doi.org/10.1016/j.ecns.2011.11.011

16. Troncon LEA. Utilization of simulated patients for clinical skills teaching and assessment. Med[Internet]. 2007 [cited 2016 Aug 15];40(2):180-91. Available from: http://revista.fmrp.usp.br/2007/vol40n2/5_utilizacao_pacientes_simulados_ensino.pdf

17. Lopreiato JO, (Ed.). Terminology \& Concepts Working Group. Healthcare Simulation Dictionary [Internet]. Orlando: SSH; 2016[cited 2016 Aug 15]. Available from: http://www.ssih.org/dictionary

18. Arafeh JMR, Hansen SS, Nichols A. Debriefing in simulated-based learning: facilitating a reflective discussion. J Perinat Neonatal Nurs [Internet]. 2010[cited 2016 Aug 10];24(4):302-9. Available from: http://www.ncbi.nlm.nih.gov/pubmed/21045608 